\title{
Implementing presidential particularism: bureaucracy and the distribution of federal grants
}

\author{
Nicholas G. Napolio \\ Department of Political Science, University of Southern California, Los Angeles, USA \\ Corresponding author. Email: napolio@usc.edu
}

(Received 8 July 2020; revised 30 November 2020; accepted 5 February 2021; first published online 5 July 2021)

\begin{abstract}
Do agencies implement the president's particularistic goals uniformly? This paper clarifies the presidential particularism literature by explicitly considering the mechanism through which the president pursues their policy goals: executive agencies. The constellation of bureaucratic agencies responsible for allocating grants plays a key role in facilitating or frustrating presidential policy priorities. Using a dataset of 21 agencies over 14 years, I find that only agencies ideologically proximate to the president engage in particularism benefiting the president. I find no evidence that politicization influences agency implementation of particularism. Critically, the moderating effect of the bureaucracy on particularism only occurs for distributive programs over which agencies have discretion. When disbursing formula grants written by Congress but administered by the bureaucracy with little or no discretion, ideological distance between agencies and presidents has no effect on particularism.
\end{abstract}

Keywords: American politics; political economy; presidency and executive politics

The power of the presidency is fundamentally dependent upon the actions of bureaucrats. Arguing that presidents direct distributive benefits to preferred constituencies like legislators do, the particularist view of the presidency finds substantial support in the literature (Berry et al., 2010; Hudak, 2014; Dynes and Huber, 2015; Kriner and Reeves, 2015; Lowande et al., 2018). However, extant studies largely overlook the implementation of particularistic policy by providing descriptive accounts of how the bureaucracy might moderate particularism in theory but nonetheless ignoring heterogeneous implementation in empirical analyses either by aggregating spending across all agencies or focusing on outlays from a single agency. Understanding the role of the bureaucracy in implementing presidential policy is integral to characterizing the modern administrative presidency. Regardless of presidential preferences, the effectiveness of presidential policy relies on compliant bureaucrats. The power of the presidency is, after all, the power to persuade (Neustadt, 1991).

Much of the research on particularism studies the distribution of federal grants and argues that presidents target outlays to co-partisans and other key constituencies. Grants, however, are disbursed by disparate agencies with varying institutional designs, preferences, and incentives (Bertelli and Grose, 2009; Arel-Bundock et al., 2015; Anderson and Potoski, 2016; Berry and Gersen, 2017; Dahlström et al., 2019). According to the Federal Assistance Award Data System (FAADS), about 200 unique agencies have disbursed grants since 2000. Agencies as different as the US Agency for International Development, Nuclear Regulatory Commission, and Department of Education disburse billions of dollars in grants every year with unique processes for drafting calls for applications and adjudicating between potential recipients developed 
in-house by each agency. This paper takes seriously the diversity of executive agencies responsible for disbursing grants and provides a nuanced account of a posited mechanism of presidential particularism: presidential control of the bureaucracy.

I show that the constellation of agencies responsible for grantmaking varies in its implementation of the president's particularistic preference to target outlays to the president's preferred constituencies. Specifically, this paper interrogates whether ideological alignment with the president and agency politicization condition bureaus' implementation of particularism benefiting the president. Using data from 21 agencies over 14 years, I test whether agencies vary in their implementation of particularism, and specifically whether ideology and politicization account for such variation.

I find that agencies ideologically proximate to the president engage in particularism while agencies ideologically distant from the president do not. I find no evidence that politicization influences agency implementation of presidential particularism. My findings suggest a more nuanced treatment of presidential particularism that takes seriously the implementation apparatus leveraged by the president to pursue their particularistic goals. Presidents do not have unilateral control over the disbursement of federal funds, even when Congress grants the Executive Branch discretion to allocate money. Instead, the individual agencies responsible for disbursing federal grants constrain the power of the president to target funds to key constituencies.

In the following text, I describe the process by which federal grants are administered, noting the various stages during the allocation process where agencies have broad discretion to disburse grants consistent with their preferences. Then, I test whether bureaucratic agencies implement the president's particularistic goals uniformly and show that only agencies ideologically aligned with the president engage in particularism on the president's behalf. Next, I conduct a placebo test on formula grants over which agencies have little, if any, discretion and show that the bureaucracy does not influence the distribution of formula grants the same way it influences discretionary ones. I conclude with a discussion of the implications of my findings for the theory of presidential particularism, the role of the bureaucracy in the American separation of powers system, and the power of the presidency.

\section{The federal grant process}

Federal grants come in many forms, but can be lumped into two broad categories: formula and program grants (sometimes called mandatory and discretionary grants, respectively). Formula grants are administered by federal agencies, but the recipients and amounts are determined by Congress. Examples of formula grants include: Medicaid, Temporary Assistance for Needy Families (TANF), and Special Needs Education grants. Program grants, on the contrary, are those for which the federal agencies administering them have discretion over both the recipient and amount based on an often competitive application process developed in-house by the agencies themselves (Kincaid, 2008; Chernick, 2014). Examples of program grants include: National Science Foundation Graduate Research Fellowship Program grants, Department of Education State Personnel Development grants, and Department of Transportation, Transportation Investment Generating Economic Recovery grants. Therefore, program grants represent opportunities for discretionary and distributive choices by bureaucrats, whereas formula grants represent the implementation of circumscribed distributive authority from Congress.

The life cycle of a program or discretionary grant consists of four stages: pre-award, award, administration, and post-award. During the pre-award stage, federal agencies develop and publish criteria for evaluating applications while applicants prepare and submit applications. Agencies then evaluate the applications they receive, occasionally using panels of experts to help make decisions. During the award stage, the terms of the grant are established. Then, the agency administers the grant during the administration stage. Finally, during the post-award stage, the agency must comply with reporting requirements to oversight committees, oversight agencies like the Office of Management and Budget or Government Accountability Office, and to databases like 
the Treasury's online database hosted at usaspending.gov. Once the program has been administered in full, it is closed out and may be audited (Keegan, 2012).

The pre-award stage, where agencies adjudicate among potential recipients, is particularly important. For program grants, no entity but the agency distributing the grant formally makes the decision about where to allocate the outlay. Each agency establishes criteria for applicants and then selects both which applicant will receive the grant from the pool of contenders and how much the grant will be worth. Thus, agencies have discretion over how they will allocate program grants in (1) the development of criteria-which may target certain potential applicants-(2) the selection of recipients-which may favor certain constituencies-and, (3) the determination of the value of the grant-which again may privilege certain partisans. The pre-award stage, then, offers multiple opportunities for agencies to make political and partisan decisions over the allocation of grant outlays: first in the development of criteria, second in the selection of recipients, and last in the valuation of the grant.

Isolating program grants represents a break from extant studies of particularism in grantmaking which tend to pool all grants and then remove programs that do not meet an arbitrary level of within-program variation in funding over time and space. ${ }^{1}$ More importantly, program grants are the appropriate venue for testing whether agencies vary in their implementation of presidential particularism since bureaucrats enjoy broad discretion when deciding how to allocate program grants. Confining the analyses to program or discretionary grants also guards against drawing improper conclusions if, for example, an agency seems to follow its principal's orders if grants are pooled simply because formula grants have been designed such that they benefit certain constituencies independent of the agencies responsible for disbursing them.

\section{Expectations}

In the following empirical analyses, I test two expectations. First, ideological distance between agencies and presidents should decrease particularistic outlays from an agency. Second, agency politicization should increase particularistic outlays from an agency.

Ideological disagreement with the president should condition an agency's willingness to engage in particularism. If agencies are aligned ideologically with the president, those agencies likely want the president and their party to stay in power and to continue implementing policies consistent with their ideology. Ultimately, presidents' aims in directing funds to co-partisans are to secure their support, win reelection, strengthen the party brand, and ensure that their party can gain or stay in power in order to implement its platform (Dynes and Huber, 2015; Kriner and Reeves, 2015).

As such, one function of particularism is to cultivate the political capital necessary to enact ideological policy. Although bureaucrats face different incentives than presidents-influence from competing principals (Bertelli and Grose, 2009; Gailmard, 2009; Potter, 2019; Potter and Shipan, 2019), good government or efficiency (Gailmard and Patty, 2007; Miller and Whitford, 2016), ideology (Clinton et al., 2012; Potter, 2019), and enlarging their budgets (Niskanen, 1971) - agencies nonetheless care about policy outcomes, particularly in their regulatory spheres, so helping the president direct funds to key constituencies may be mutually beneficial by aiding the reelection campaign of the president and that of their co-partisans. Additionally, since bureaucrats generally desire larger budgets and presidents typically request more in appropriations to agencies with whom they are ideologically aligned (Bolton, 2020), agencies ideologically aligned with the president stand to gain if the incumbent stays in office and can help them do so by directing funds to districts important to their reelection.

\footnotetext{
${ }^{1}$ The analyses to come are robust to only including grants disbursed pursuant to high-variation programs, as in other work (see the Appendix "Reanalysis with High-Variance Programs"). This subsetting of the data, however, conflates high-variance formula grants, over which agencies have little discretion, with program grants over which agencies have discretion, and excludes low-variance program grants, leading both to false inclusions and exclusions, so it is suboptimal.
} 
Therefore, agencies ideologically aligned with presidents should allocate more funding to presidential co-partisans by implementing the president's particularist agenda. The logic for misaligned agencies is similar. Agencies distant from the president likely are not as invested in the incumbent president's and their party's success in future elections and therefore may not be willing to direct outlays to key constituencies and instead substitute in their own best judgment or standard operating procedures despite the president's preference for particularism. Additionally, agencies ideologically distant from the incumbent president stand to gain from their replacement with a friendlier chief executive who may seek more appropriations for those agencies (Bolton, 2020).

Politicization-the extent to which an agency is filled with political appointees rather than careerists-may also condition an agency's willingness to engage in particularism. How politicization may affect the implementation of particularism is less clear however. Some studies suggest that politicization does result in agency responsiveness to the president since the president is able to stack agencies with loyalists (Berry and Gersen, 2017; Lowande, 2019), while others suggest the opposite since politicization often reduces bureaucratic capacity so much so that agencies cannot implement their principal's policies even if they want to (Huber and McCarty, 2004; Huber, 2007; Lewis, 2010; Kennedy, 2015). The most straightforward expectation is that by inserting presidential loyalists into agencies, those agencies will be more likely to implement the president's particularist agenda, but reasonable theories predict opposite results.

\section{Data and empirical strategy}

To test whether the bureaucracy moderates presidential particularism, I compiled an original dataset containing information on discretionary grant outlays from each agency to each congressional district in each Congress from the 106th (1999-2000) to 112th (2011-2012) Congress. I collected data on grants from usaspending.gov which compiles FAADS data at the level of the outlay from each federal agency and reports, among other things, its amount, its recipient's congressional district, and whether it was disbursed pursuant to a program or congressional formula. $^{2}$ The unit of analysis is the agency-congressional district-Congress and each observation represents how much in outlays (in 2018 dollars) each congressional district received from each agency in each Congress. I removed all grants that were allocated based on statutory formulas to isolate only those grants that were subject to agency discretion.

Formula grants, however, offer a nice placebo test. If the results are driven by secular trends in grant disbursement, then we should observe the same results from estimating the same models on formula grants, over which agencies have little, if any, discretion. But if the bureaucracy moderates presidential particularism in the allocation of grants, there should only be a relationship between particularism and agency ideological misalignment with the president or politicization for program grants.

The dataset comprises 21 agencies and over \$3.9 trillion in outlays. I aggregate outlays to agencies' highest organizational level: the department or independent agency (Berry and Gersen, 2017). The aggregation process resulted in a dataset of 63,075 observations. All agencies but the Department of Homeland Security were in operation throughout the entire period, each of which forms a pair with each of the 435 members of Congress (MC) in each of the seven Congresses $(20 \times 435 \times 7=60,900)$, then the Department of Homeland Security forms a pair with each of the $435 \mathrm{MCs}$ for the five Congresses it was in operation $(435 \times 5=2175)$, leading to a final dataset of $60,900+2175=63,075$ observations at the agency-district-Congress level.

The dependent variable is the logged outlays $(+1)$ in 2018 dollars from each agency to each congressional district in each Congress. The first independent variable of interest is presidential co-partisan which takes the value of one if the MC representing the congressional district receiving the outlay is from the same party as the president in a given Congress, and zero otherwise.

\footnotetext{
${ }^{2}$ Since I am interested in the implementation process of appropriations, spending data are appropriate (Hammond and Rosenstiel, 2020).
} 
To construct the second independent variable of interest, agency-president distance, I take the absolute value of the difference between each agency's Chen and Johnson (2015) campaign finance based ideal point estimate and the president's DW-NOMINATE ideal point estimate in each Congress, which are measured on the same scale. ${ }^{3}$ The third independent variable of interest is agency politicization, which I measure as the ratio of political appointees to the number of career senior executive service members following previous study (see, e.g., Lewis 2010; Wood and Lewis 2017; Lowande 2019). I also include a host of control variables at both the agency- and legislator-levels. ${ }^{4}$

With these data, I then estimate a series of generalized least squares regression models to assess agency implementation of presidential particularism. I estimate variants of the following general model:

$$
\begin{aligned}
\ln (\text { Outlays })_{\mathrm{ijt}}= & \beta_{0}+\beta_{1} \text { Presidential Co-Partisan }_{\mathrm{jt}}+\beta_{2} \text { Agency-President Distance }_{\mathrm{it}} \\
& +\beta_{3} \text { Politicization }_{\mathrm{it}}+\beta_{4} \text { Presidential Co-Partisan }_{\mathrm{jt}} \times \text { Agency-President Distance }_{\mathrm{it}} \\
& +\beta_{5} \text { Presidential Co-Partisan }_{\mathrm{jt}} \times \text { Politicization }_{\mathrm{it}}+\xi \mathbf{X}_{\mathrm{ijt}}+\alpha_{\mathrm{ij}}+\delta_{\mathrm{t}}+\varepsilon_{\mathrm{ijt}}
\end{aligned}
$$

where subscript $i$ indexes agencies, subscript $j$ indexes members of Congress, subscript $t$ indexes Congresses, $\mathbf{X}$ is a matrix of covariates, $\xi$ is a vector of coefficients attending the covariates, $\alpha$ is a vector of agency-legislator pair fixed effects, and $\delta$ is a vector of Congress fixed effects. I center each of the continuous independent variables to zero as its mean and standardize them by the standard deviation of their residualized values after absorbing variation from agency-legislator and Congress fixed effects (Mummolo and Peterson, 2019), thus coefficients should be interpreted as the change in logged outlays given a standard, within-agency increase in the independent variables.

Formally, if agencies ideologically distant from the president implement particularistic policy less vigorously than those ideologically proximate, we would expect $\beta_{2}+\beta_{4}<0$ (i.e., increasing ideological distance decreases outlays to presidential co-partisans) and $\beta_{2}>0$ (i.e., increasing ideological distance increases outlay to presidential contra-partisans), which implies $\beta_{4}<0$. If more politicized agencies implement particularistic policy less vigorously than non-politicized one, we would expect $\beta_{3}+\beta_{5}>0$ (i.e., increasing politicization increases outlays to presidential co-partisans) and $\beta_{3}<0$ (i.e., increasing politicization decreases outlays to presidential co-partisans), which implies $\beta_{5}>0$.

The agency-legislator fixed effects adjust for any time-invariant characteristics that may affect the distribution of federal grants including, but not limited to, agency structure and independence (Selin, 2015), ${ }^{5}$ workforce skill (Richardson et al., 2018), legislator district, legislator gender (Anzia and Berry, 2011), and the unobservable aspects of the relationship between each legislator and

\footnotetext{
${ }^{3}$ Using the Chen and Johnson (2015) measure of agency ideal points is optimal since they are dynamic, varying with each presidential term. Alternative measures of agency ideal points are static, thus obscuring the dynamic nature of bureaucratic ideology induced by changing appointees and civil servants, and not estimated on the same scale as other political actors, so calculating the spatial distance between bureaucratic and political ideal points requires the imposition of untestable assumptions to map political ideal points into bureaucratic ones (e.g., Richardson et al., 2018).

${ }^{4}$ Specifically, I include whether each member of Congress in each Congress is in the majority party, sits on the appropriations committee, sits on the ways and means committee, won their previous election with a margin less than 0.05 , each district's logged population, and logged median income, and the distance between each agency's Chen and Johnson (2015) ideal point estimate and each member's DW-NOMINATE ideal point estimate.

${ }^{5}$ Agency independence is conceptually related, yet distinct, from politicization. My empirical strategy leveraging within-agency variation does not allow me to test how independence affects particularism since independence is timeinvariant. However, in the Appendix "Reanalysis by Agency Structure Subsets," I separate out cabinet departments from independent agencies and find similar results for both kinds of agencies.
} 
Table 1. Agency ideology, politicization, and presidential particularism

\begin{tabular}{|c|c|c|c|c|}
\hline & \multicolumn{4}{|c|}{ Dependent variable } \\
\hline & \multicolumn{4}{|c|}{ Logged outlays } \\
\hline & (1) & (2) & (3) & (4) \\
\hline Presidential & $0.536^{\star \star \star}$ & $0.451^{\star \star \star}$ & $0.396^{\star \star \star}$ & -0.026 \\
\hline Co-partisan & $(0.144)$ & $(0.135)$ & $(0.042)$ & $(0.113)$ \\
\hline Agency-president & & & $0.350^{\star \star \star}$ & $0.304^{\star \star \star}$ \\
\hline Distance & & & $(0.035)$ & $(0.088)$ \\
\hline Politicization & & & $-0.064^{\star \star \star}$ & $-0.081^{\star \star \star}$ \\
\hline Ratio & & & $(0.020)$ & $(0.020)$ \\
\hline Pres. co-partisan $\times$ & & & $-0.805^{\star \star \star}$ & $-0.713^{\star \star \star}$ \\
\hline Ag.-pres. dist. & & & $(0.057)$ & $(0.171)$ \\
\hline Pres. co-partisan $x$ & & & $-0.063^{\star \star \star}$ & $-0.032^{\star \star \star}$ \\
\hline Politicization ratio & & & $(0.008)$ & $(0.008)$ \\
\hline$\beta_{2}+\beta_{4}$ & & & $-0.455^{\star \star \star}$ & $-0.409^{\star \star \star}$ \\
\hline (Ag.-Pres. Dist.) & & & $(0.0034)$ & $(0.088)$ \\
\hline$\beta_{3}+\beta_{5}$ & & & $-0.127^{\star \star \star}$ & $-0.133^{\star \star \star}$ \\
\hline (Politicization) & & & $(0.019)$ & $(0.019)$ \\
\hline Congress FEs & Yes & Yes & Yes & Yes \\
\hline Legislator FEs & Yes & Yes & & \\
\hline Agency-Legislator FEs & & & Yes & Yes \\
\hline Time-varying covariates & & Yes & & Yes \\
\hline Observations & 3,045 & 3,045 & 63,075 & 63,075 \\
\hline Adjusted $R^{2}$ & 0.610 & 0.620 & 0.592 & 0.596 \\
\hline
\end{tabular}

${ }^{\star} p<0.1 ;{ }^{* \star} p<0.05 ;{ }^{* \star *} p<0.01$

Note: Unit of analysis for models 1 and 2 is the district-Congress and for models 3 and 4 is the agency-district-Congress.

Heteroskedasticity-corrected errors clustered by legislator (models 1 and 2) and agency-legislator (models 3 and 4) reported in parentheses. Model 2 controls for whether each member of Congress in each Congress is in the majority party, sits on the appropriations committee, sits on the ways and means committee, whether each member of Congress won their previous election with a margin less than 0.05 , each district's logged population and logged median income, and model 4 additionally controls for the distance between each agency's Chen and Johnson (2015) ideal point estimate and each member's DW-NOMINATE ideal point estimate.

each agency. The Congress fixed effects adjust for any common shocks experienced by all agencies such as the president's party (Reingewertz and Baskaran, 2019), the majority party in the House of Representatives, and national economic health. This dual fixed effects design allows for identification from within-agency-legislator variation in the key independent variables. Identification comes from the same representative changing from presidential co-partisan to presidential contra-partisan or vice versa, and changes in the ideological distance between the same agency and the president over time.

\section{Results}

Table 1 reports the parameters estimated from the model in Equation 1. ${ }^{6}$ First, I report the aggregate level of particularism in the sample by aggregating the data to the legislator-Congress level. The coefficients on presidential co-partisan in models 1 and 2 indicate that, on average, congressional districts represented by legislators who share the president's party receive more in outlays.

This estimate is consistent with prior research on grants and particularism and indicates that my sample of agencies, on average, displays particularism (Berry et al., 2010; Hudak, 2014; Dynes and Huber, 2015; Kriner and Reeves, 2015).

Models 3 and 4 disaggregate the data to the agency-district-Congress level and show that particularism is primarily implemented by agencies ideologically proximate to the president. Figure 1 displays the marginal effect of presidential co-partisanship on outlays at different levels of agencypresident distance and politicization derived from model 4 in Table 1. Agencies ideologically

\footnotetext{
${ }^{6}$ Since estimated coefficients on "control variables generally have no structural interpretation themselves," I decline to include them in tables (Hünermund and Louw, 2020).
} 

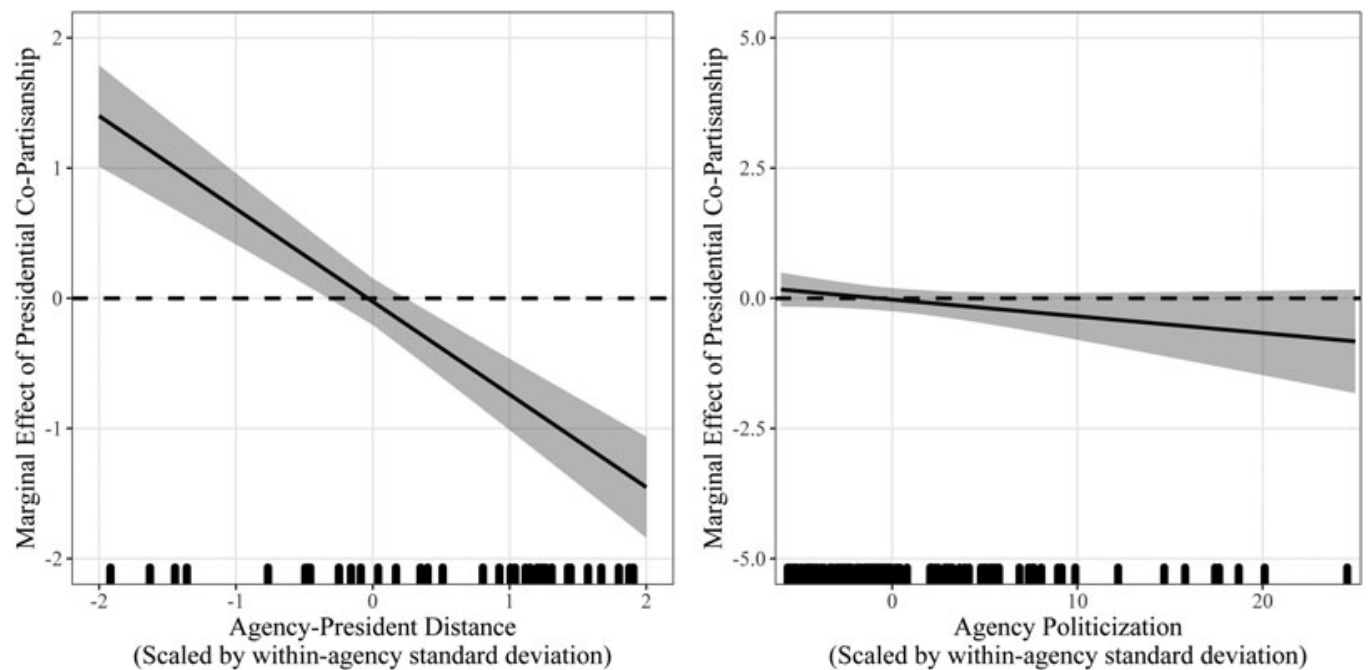

Fig. 1. Particularism by agency-president distance and politicization. The figure is derived from model 4 in Table 1 . Left panel displays the marginal effect of presidential co-partisan at all observed levels of agency-president distance and right panel displays the marginal effect of presidential co-partisan at all observed levels of agency politicization. The rug along the $\mathrm{x}$-axis displays the densities of the respective variables.

proximate to the president allocate more to presidential co-partisans than contra-partisans. Ideologically distant agencies, on the contrary, allocate the same or less in outlays to districts represented by presidential co-partisans.

The results provide no evidence that politicization influences agency implementation of presidential particularism since the marginal effect of presidential co-partisanship does not vary across different levels of agency politicization. Although the coefficient on politicization is negative, indicating that presidential contra-partisans receive less in outlays as agencies become more politicized, the sum of $\beta_{3}$ and $\beta_{5}$ is also negative, indicating that presidential contra-partisans also receive less in outlays as agencies become more politicized. Furthermore, the effect sizes are quite small. A standard, within-agency increase in politicization reduces outlays to co-partisans by about 12 percent and to contra-partisans by about 7.8 percent. If anything, more politicized agencies allocate more funding to contra-partisans than co-partisans, but not by much. Ideological distance between agencies and presidents on the other hand has a much more pronounced effect. A standard, within-agency increase in agency-president distance increases outlays to contra-partisans by about 35 percent and decreases outlays to co-partisans by about 34 percent.

Table 2 reports expected outlays for co- and contra-partisans, and the difference between the two, at different levels of agency-president distance. ${ }^{7}$ An agency one within-agency standard deviation below the mean of agency-president distance allocates, on average, $\$ 6.4$ million more in funding to presidential co-partisans, while an agency one within-agency standard deviation above the mean allocates, on average, $\$ 5.9$ million less over the course of an average two-year congressional session.

\subsection{Placebo test with formula grants}

In the main analysis above, I report results only from program grants over which agencies have much discretion. If the results are driven by secular trends in grant disbursement rather than bureaucratic discretion, we should observe the same results from estimating the same model on

\footnotetext{
${ }^{7}$ Since I find no evidence that agency politicization influences agency implementation of presidential particularism, I decline to calculate substantive effects.
} 
Table 2. Substantive effects, agency-president distance

\begin{tabular}{lccr}
\hline $\begin{array}{c}\text { Agency-president } \\
\text { distance }\end{array}$ & $\begin{array}{c}\text { Co-partisan } \\
\text { expected outlay }\end{array}$ & $\begin{array}{c}\text { Contra-partisan } \\
\text { expected outlay }\end{array}$ & $\begin{array}{c}\text { Difference } \\
\text { (co-partisan advantage) }\end{array}$ \\
\hline Aligned (-1 SD) & $\$ 12.6 \mathrm{M}$ & $\$ 6.15 \mathrm{M}$ & $\$ 6.42 \mathrm{M}$ \\
Mean & $\$ 8.32 \mathrm{M}$ & $\$ 8.37 \mathrm{M}$ & $-\$ 0.05 \mathrm{M}$ \\
Misaligned (+1 SD) & $\$ 5.51 \mathrm{M}$ & $\$ 11.37 \mathrm{M}$ & $-\$ 5.87 \mathrm{M}$ \\
\hline
\end{tabular}

Note: Expected values calculated with estimates from model 4 in Table 1 holding continuous variables at their means, binary variables at their modes, and adjusting for the estimated, median intercept of the agency-legislator fixed effects. Standard deviations measured as the standard deviation of the residualized values of agency-president distance with respect to agency-legislator and Congress fixed effects following Mummolo and Peterson (2019).

Table 3. Placebo test with formula grants

\begin{tabular}{|c|c|c|c|c|}
\hline & \multicolumn{4}{|c|}{ Dependent variable } \\
\hline & \multicolumn{4}{|c|}{ Logged outlays } \\
\hline & \multirow{2}{*}{\multicolumn{2}{|c|}{ Program grants }} & \multicolumn{2}{|c|}{ Formula grants } \\
\hline & & & \multicolumn{2}{|c|}{ (Placebo test) } \\
\hline & (1) & (2) & (3) & (4) \\
\hline Presidential & $0.396^{\star \star \star}$ & -0.026 & $0.198^{\star \star \star}$ & -0.072 \\
\hline Co-partisan & $(0.042)$ & $(0.113)$ & $(0.032)$ & $(0.079)$ \\
\hline Agency-president & $0.350^{\star \star \star}$ & $0.304^{\star \star \star}$ & $0.307^{\star \star \star}$ & $0.124^{\star \star}$ \\
\hline distance & $(0.035)$ & $(0.088)$ & $(0.030)$ & $(0.056)$ \\
\hline Politicization & $-0.064^{\star \star \star}$ & $-0.081^{\star \star \star}$ & $-0.168^{\star \star \star}$ & $-0.175^{\star \star \star}$ \\
\hline Ratio & $(0.020)$ & $(0.020)$ & $(0.020)$ & $(0.020)$ \\
\hline Pres. co-partisan $\times$ & $-0.805^{\star \star \star}$ & $-0.713^{\star \star \star}$ & $-0.403^{\star \star \star}$ & -0.042 \\
\hline Ag.-pres. dist. & $(0.057)$ & $(0.171)$ & $(0.053)$ & $(0.109)$ \\
\hline Pres. co-partisan $\times$ & $-0.063^{\star \star \star}$ & $-0.032^{\star \star \star}$ & 0.0001 & $0.013^{\star}$ \\
\hline Politicization ratio & $(0.008)$ & $(0.008)$ & $(0.007)$ & $(0.007)$ \\
\hline$\beta_{2}+\beta_{4}$ & $-0.455^{\star \star \star}$ & $-0.409^{\star \star \star}$ & $-0.096^{\star \star \star}$ & $0.082^{*}$ \\
\hline (Ag.-Pres. dist.) & $(0.034)$ & $(0.088)$ & $(0.029)$ & $(0.056)$ \\
\hline$\beta_{3}+\beta_{5}$ & $-0.127^{\star \star \star}$ & $-0.113^{\star \star \star}$ & $-0.167^{\star \star \star}$ & $-0.113^{\star \star \star}$ \\
\hline (Politicization) & $(0.019)$ & $(0.019)$ & $(0.020)$ & $(0.020)$ \\
\hline Congress FEs & Yes & Yes & Yes & Yes \\
\hline Agency-Legislator FEs & Yes & Yes & Yes & Yes \\
\hline Time-varying covariates & & Yes & & Yes \\
\hline Observations & 63,075 & 63,075 & 63,075 & 63,075 \\
\hline Adjusted $R^{2}$ & 0.592 & 0.596 & 0.618 & 0.619 \\
\hline
\end{tabular}

${ }^{*} \mathrm{p}<0.1 ;{ }^{* \star} \mathrm{p}<0.05 ;{ }^{* \star *} \mathrm{p}<0.01$

Note: Unit of analysis is the agency-district-Congress. Heteroskedasticity-corrected errors clustered by agency-legislator reported in parentheses. Models 2 and 4 control for whether each member of Congress in each Congress is in the majority party, sits on the appropriations committee, sits on the ways and means committee, whether each member of Congress won their previous election with a margin less than 0.05 , each district's logged population and logged median income, and for each agency's politicization ratio for each Congress, and the distance between each agency's Chen and Johnson (2015) ideal point estimate and each member's DW-NOMINATE ideal point estimate.

formula grants over which agencies have little, if any, discretion. For the main analysis to pass the placebo test, it must be the case that the marginal effect of presidential co-partisan does not vary with agency-president distance. ${ }^{8}$

In other words, it must be the case that particularism, or the advantage to presidential co-partisans, does not vary with the ideological alignment between the president and the disbursing agency.

Formally, to pass the placebo test, it must be that $\beta_{4}^{\text {Placebo }}<\beta_{4}^{\text {Main }}$ or, more conservatively, that $\beta_{4}^{\text {Placebo }} \leq 0$. Table 3 reproduces the main analysis in models 1 and 2 and reports the parameters

\footnotetext{
${ }^{8}$ Since the effect of presidential co-partisanship does not vary with politicization even when agencies have discretion, this section focuses on probing the robustness of the ideology finding.
} 

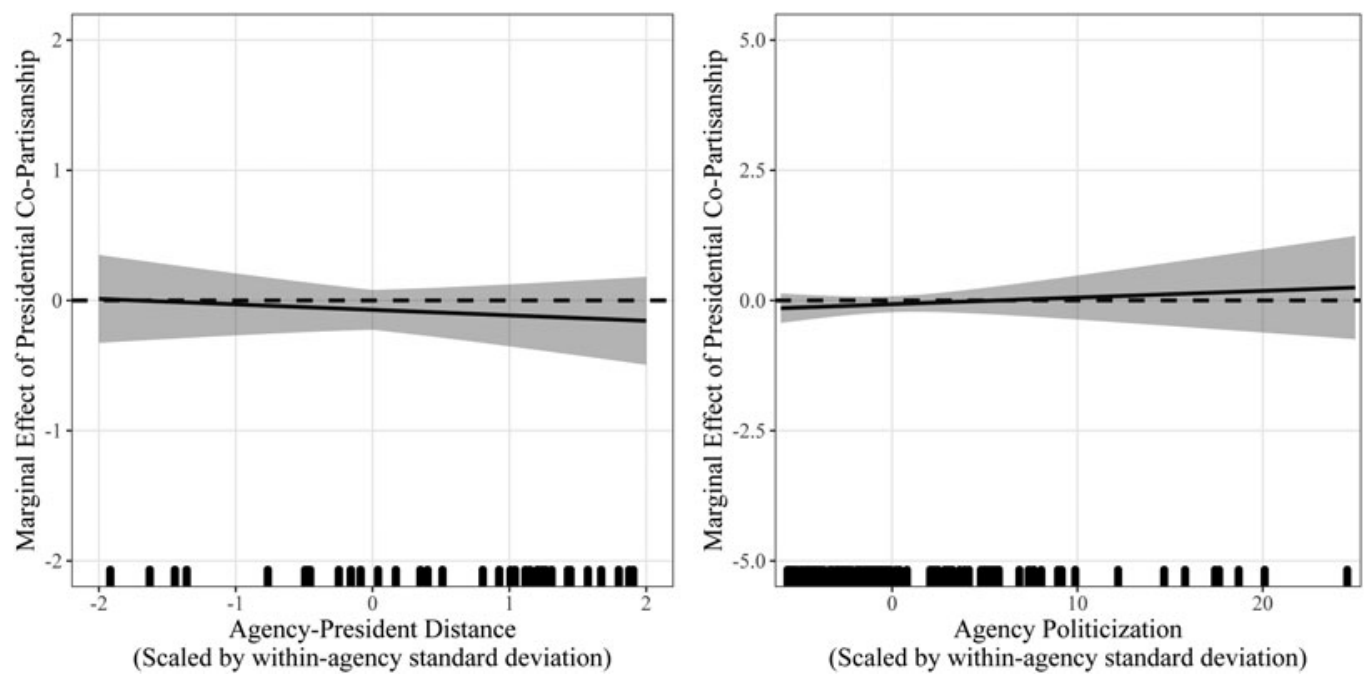

Fig. 2. Placebo test: particularism in formula grants. The figure is derived from model 4 in Table 3 . The rug along the $x$-axis displays the density of each variable.

estimated for the placebo model on formula grants in models 3 and 4 . For the placebo model without covariates, the effect $\left(\beta_{4}^{\text {Placebo }}\right)$ is only about half of the effect in the main model, passing the weaker placebo test. More importantly, once including covariates, the effect disappears and is null ( $\mathrm{p} \approx 0.35$ ), passing the more conservative test. The weak politicization findings for program grants are replicated for formula grants, so I cannot rule out that secular trends in grant disbursement, and not bureaucratic discretion, account for the politicization results in Table 1. I can rule out that secular trends account for the ideology findings however.

The main analysis of ideological distance on program grants passes the placebo test, indicating that ideological dissimilarity between agencies and presidents only affects the distribution of federal grants when the agencies responsible for administering those grants have discretion over their distribution. When agencies do not have discretion, as with formula grants written by Congress, policy disagreement among presidents and agencies has no effect on whether agencies reward presidential co-partisans with federal funds. To see the difference more clearly, Figure 2 displays the marginal effect of presidential co-partisan for formula grants, over which agencies have little discretion. The slope is almost exactly zero, unlike for program grants in the main analysis in Figure 1.

\section{Conclusion}

In this paper, I have shown that executive agencies do not uniformly implement the president's particularistic policy preferences. Only agencies ideologically proximate to the president allocate more in grant funding to presidential co-partisans. Ideologically distant agencies do not engage in particularism. Critically, the bureaucracy only moderates presidential particularism when disbursing program grants, over which agencies have discretion to create application criteria, select recipients, and choose the value of the grant. When disbursing formula grants written by Congress, bureaucratic ideology has no effect on presidential particularism.

The findings presented here suggest a more nuanced treatment of presidential particularism, taking seriously the implementation apparatus with which presidents must contend in order to pursue their particularistic goals. The power of the presidency is the power to persuade (Neustadt, 1991), and conclusions about presidential power that rely on the president's ability to direct benefits to their preferred constituents must take into account that presidents have 
not persuaded and cannot persuade every agency in the bureaucracy to implement their particularistic goals. Agencies do not implement policy blindly, nor do they acquiesce in every order from the president. Rather, federal agencies are active players in the contestation and formulation of public policy and a critical part of the checks on presidential power and balances between institutions in the American political system (Miller and Whitford, 2016).

This paper complements a growing body of literature on presidential power that interrogates the agency problems inherent in the pursuit of presidential policy preferences. Regardless of presidential preferences, the effectiveness of presidential policy relies on compliant bureaucrats (see Lowande and Rogowski 2020 for an overview). Even for the hallmark of unilateral action, the executive order, presidential policy directives are not self-enforcing (Rudalevige, 2012; Kennedy, 2015). This paper has shown that presidential power to funnel benefits to key constituencies also is not self-enforcing. Only agencies aligned with the president implement the president's particularistic agenda.

Supplementary material. The supplementary material for this article can be found at https://doi.org/10.1017/psrm.2021.29

\section{References}

Anderson SE and Potoski M (2016) Agency structure and the distribution of federal spending. Journal of Public Administration Research and Theory 26, 461-474.

Anzia SF and Berry CR (2011) The Jackie (and Jill) Robinson effect: why do congresswomen outperform congressmen? American Journal of Political Science 55, 478-493.

Arel-Bundock V, Atkinson J and Potter RA (2015) The limits of foreign aid diplomacy: how bureaucratic design shapes aid distribution. International Studies Quarterly 59, 544-556.

Berry CR and Gersen JE (2017) Agency design and political control. Yale Law Journal 126, 1002.

Berry CR, Burden BC and Howell WG (2010) The president and the distribution of federal spending. American Political Science Review 104, 783-799.

Bertelli AM and Grose CR (2009) Secretaries of pork? a new theory of distributive public policy. The Journal of Politics 71, 926-945.

Bolton A (2020) Ideology, unionization, and personnel politics in the federal budget process. Journal of Public Administration Research and Theory 1-18.

Chen J and Johnson T (2015) Federal employee unionization and presidential control of the bureaucracy: estimating and explaining ideological change in executive agencies. Journal of Theoretical Politics 27, 151-174.

Chernick HA (2014) The us grant system. In S Payson (ed). Public Economics in the United States: How the Federal Government Analyzes and Influences the Economy. Santa Barbara, CA: ABC-CLIO, pp. 341-374.

Clinton JD, Bertelli A, Grose CR, Lewis DE and Nixon DC (2012) Separated powers in the United States: the ideology of agencies, presidents, and congress. American Journal of Political Science 56, 341-354.

Dahlström C, Fazekas M and Lewis DE (2019) Agency design, favoritism and procurement in the United States. Working Paper 2019:4, QoG Institute.

Dynes AM and Huber GA (2015) Partisanship and the allocation of federal spending: do same-party legislators or voters benefit from shared party affiliation with the president and house majority? American Political Science Review 109, 172-186.

Gailmard S (2009) Multiple principals and oversight of bureaucratic policymaking. Journal of Theoretical Politics 21, 161186.

Gailmard S and Patty JW (2007) Slackers and zealots: civil service, policy discretion, and bureaucratic expertise. American Journal of Political Science 51, 873-889.

Hammond B and Rosenstiel L (2020) Measuring the influence of political actors on the federal budget. American Political Science Review 114(2), 603-608.

Huber GA (2007) The Craft of Bureaucratic Neutrality: Interests and Influence in Governmental Regulation of Occupational Safety. New York, NY: Cambridge University Press.

Huber JD and McCarty N (2004) Bureaucratic capacity, delegation, and political reform. American Political Science Review 98(3), 481-494.

Hudak J (2014) Presidential Pork: White House Influence over the Distribution of Federal Grants. Washington, DC: Brookings Institution Press.

Hünermund $\mathbf{P}$ and Louw B (2020) On the nuisance of control variables in regression analysis. arXiv preprint arXiv:2005.10314.

Keegan N (2012) Federal grants-in-aid administration: a primer. Congressional Research Service. 
Kennedy JB (2015) “'Do this! do that!' and nothing will happen” Executive orders and bureaucratic responsiveness. American Politics Research 43, 59-82.

Kincaid J (2008) Federal grants. In DP Haider-Markel, MA Card, RK Gaddie, G Moncrief and KT Palmer (eds). Political Encyclopedia of U.S. States and Regions. Washington, DC: CQ Press, pp. 764-766.

Kriner DL and Reeves A (2015) The Particularist President: Executive Branch Politics and Political Inequality. New York: Cambridge University Press.

Lewis DE (2010) The Politics of Presidential Appointments: Political Control and Bureaucratic Performance. Princeton, NJ: Princeton University Press.

Lowande K (2019) Politicization and responsiveness in executive agencies. The Journal of Politics 81, 33-48.

Lowande K and Rogowski JC (2020) Presidential unilateral power. Annual Review of Political Science 24, 21-43.

Lowande KS, Jenkins JA and Clarke AJ (2018) Presidential particularism and US trade politics. Political Science Research and Methods 6, 265-281.

Miller GJ and Whitford AB (2016) Above Politics: Bureaucratic Discretion and Credible Commitment. New York, NY: Cambridge University Press.

Mummolo J and Peterson E (2019) Improving the interpretation of fixed effects regression results. Political Science Research and Methods 6, 829-835.

Neustadt RE (1991) Presidential Power and the Modern Presidents: The Politics of Leadership from Roosevelt to Reagan. New York, NY: Simon \& Schuster.

Niskanen W (1971) Bureaucracy and Representative Government. London, England: Aldine Publishing Company.

Potter RA (2019) Bending the Rules: Procedural Politicking in the Bureaucracy. Chicago, IL: University of Chicago Press.

Potter RA and Shipan CR (2019) Agency rulemaking in a separation of powers system. Journal of Public Policy 39, 89-113.

Reingewertz Y and Baskaran T (2019) Distributive spending and presidential partisan politics. Public Choice 185, 65-85.

Richardson MD, Clinton JD and Lewis DE (2018) Elite perceptions of agency ideology and workforce skill. The Journal of Politics 80, 303-308.

Rudalevige A (2012) The contemporary presidency: executive orders and presidential unilateralism. Presidential Studies Quarterly 42, 138-160.

Selin JL (2015) What makes an agency independent?. American Journal of Political Science 59, 971-987.

Wood AK and Lewis DE (2017) Agency performance challenges and agency politicization. Journal of Public Administration Research and Theory 27, 581-595.

Cite this article: Napolio NG (2023). Implementing presidential particularism: bureaucracy and the distribution of federal grants. Political Science Research and Methods 11, 180-190. https://doi.org/10.1017/psrm.2021.29 